\title{
Characterization of Biodiesel from residual friture oil, sunflower, through the ethanolic base transesterification process
}

Characterization of Biodiesel from residual friture oil, sunflower, through the ethanolic base transesterification process

\author{
${ }^{2}$ Hugo Jimenéz-Pacheco, ${ }^{1}$ Javier Alonso Villegas Aragón, ${ }^{1}$ María del Carmen Camiña Pacheco, ${ }^{1}$ Gregorio \\ Urbano Palma Figueroa, ${ }^{1}$ Lilia Mary Miranda Ramos \\ ${ }^{1}$ Escuela Profesional de Ingeniería Química, Universidad Nacional de San Agustín de Arequipa, Arequipa, Perú. \\ ${ }^{2}$ Vicerrectorado de Investigación, Universidad Catolica de Santa María, Arequipa, Perú.
}

\section{INFORMACIÓN}

Historia del Artículo

Recepción: 15/07/2019

Revisión: 05/08/2019

Aceptación: 21/09/2019

\section{Key Words}

Biodiesel, residual frying oil, transesterification.

\section{DOI}

https://doi.org/10.35286/veritas v20i2.243

\begin{abstract}
The conservation of the environment is becoming a global concern for the use of fuels from fossil waste, and the production of biodiesel from renewable sources is being considered as an eco-friendly alternative since oleaginous organic waste presents potential as Energy condition An important aspect is to minimize the impacts generated by this waste under different conditions, and an operation related to the aspect is the elaboration and comparison of biodiesel obtained from residual frying oils with biodiesel produced with sunflower oil through the transesterification process based on ethanol. The evaluation was carried out on a laboratory scale with parameters and specifications found in the Peruvian Technical Standard for Biodiesel (NTP321.12-200-2008), with the exception of water content, and the oxidative stability index (IEO). The following results were obtained $739.7 \mathrm{mg} / \mathrm{kg}$ and 1.5 hours and these do not meet the standards whose minimum reference corresponds to $500 \mathrm{mg} / \mathrm{kg}$ and 3 hours, respectively. The yield of residual oil and sunflower corresponds to $68.5 \%$ and $85.2 \%$ respectively. The research work establishes that the production of biodiesel from residual frying oil by the ethanol-based transesterification process is significantly less than the process with sunflower oilseeds, showing greater performance and stability.
\end{abstract}

\section{INTRODUCTION}

Most of all the energy consumed in the world comes from limited sources, such as oil, carbon and natural gas, so it is essential to look for alternative sources of energy. In this context, biodiesel obtained from residual oil constitutes an energy alternative, being an environmentally friendly product, on the other hand the low cost raw material and its high availability is used (Ji Zhang, 2013) (Abd El -Fatah Abomohra, 2017). According to the National Institute of Industrial Technology of Argentina, each liter of residual frying oil contaminates almost a thousand liters of water. There are several attempts to use the residual frying oil in different methodologies, the heterogeneous catalyst for the production of biodiesel is a preferred route for its easier recovery and without treatment demand (G. Baskar, 2017), with the use of liquid enzymes, while the second alternative analyzed the use of immobilized enzymes for the transesterification of castor oil (Thalles A. Andrade, 2018), and one of the study alternatives is the application of microbial oil that currently shows promise (Lalit R Kumar , 2018). In the states of New

Correspondencia:

Hugo Jimenéz-Pacheco

hjimenezp@unsa.edu.pe
Hampshire and Hawaii in the United States, residual frying oil is collected to produce biodiesel that is mixed with diesel to move naval ships and some official vehicles. In Europe, Austria stands out, where the McDonald's fast food chain developed a biodiesel production project from frying oils used in its 135 stores. The generated biodiesel is used in public transport in the city of Graz, located in southeastern Austria, which has 250,099 inhabitants, which makes it the second largest city. In South America the nations that lead the production of biodiesel are Argentina and Brazil, in Argentina the Biosphere Foundation reuses the residual frying oil generated by the citizens of the city Tres Arroyos, they also have sub-projects that are part of the macro Brazil biodiesel project, in which universities collect used oil, to produce biodiesel and use it as fuel for public transport vehicles (Benjamin M. Wood, 2014). Studies of biodiesel production have been carried out using residual frying oil using the ethyl route (Mariana Lara Menegazzo, 2015) (Sahar, 2018), and these fat residues have been considered as a profitable raw material for biodiesel production due Due to its high lipid content and relatively low collection cost, however, the costly pretreatment of this contaminated resource is currently the barrier to the commercialization of biodiesel (Nghiep Nam Tran, 2018). The resulting ester mixture had physicochemical properties similar to those of petroleum-derived diesel. After analyzing the viscosity, density, cetane number, glare point and fog point, it was concluded that the biodiesel was within the specifications. Studies determined the thermal 
efficiencies for biodiesel mixtures of discarded cooking oil that were lower than those of diesel oil (KA Abed, 2018), as well as for the specific energy consumption values in fuel mixed with different mixtures were observed. Substantial thermal efficiency for mixing ratio range from B20 to B50 in engine combustion improving emissions (Ali MA Attia, 2015). The main variables that affect the performance and kinetics of the transesterification reaction are the quality of the raw material, the type and quantity of catalyst, the type of alcohol, the alcohol / oil ratio and the molar ratios, in addition to the conditions operational, such as temperature, pressure and agitation (Benjamin M. Wood, 2014). Another aspect to consider is the different degrees of water contamination and increased oxidative instability due to its hygroscopicity. Fatty acid content and humidity are the parameters that determine the viability of the transesterification process of vegetable oil. To perform the complete reaction the acidity should not be more than $0.5 \%(\mathrm{w} / \mathrm{w})$. In addition, both excess and catalyst deficiency can result in the formation of soap combined with the presence of moisture that decreases the yield of the reaction (Ji Zhang, 2013). The resulting saponification reaction can cause an increase in viscosity and interfere with the reaction and separation of glycerol (Wang Yi, 2015). If the residual frying oil has a high degree of fatty acids, they are inferred in the esterification, which results in the application of previous treatments and the use of acids (Rocio Maceiras, 2011), the most commonly used techniques being sulfuric acids, phosphoric acid, among others (J. Dantas, 2018). In alkaline methanolysis processes, the most commonly used catalysts are potassium hydroxide or sodium hydroxide. One of the methodologies is the transesterification of an equilibrium reaction that requires an excess of alcohol to drive the reaction to the right, the maximum conversion is used with a 6:1 molar ratio, with a yield greater than $98 \%$. In the event that there is an increase in the solubility of glycerin, the reaction of glycerin on the left, lowering the yield of the esters (Sahar, 2018). This paper studies the biodiesel produced from residual frying oil and compares it with biodiesel produced from vegetable oil from sunflower.

\section{MATERIALS AND METHODS}

The materials used are in accordance with the basic transesterification process, they were made up of a fluid in the process, P.A ethanol, sodium hydroxide, residual frying oil used and sunflower oil. The material consisted of a $500 \mathrm{ml}$ separating funnel, a $500 \mathrm{ml}$ specimen, a digital scale, a 500 $\mathrm{ml}$ beaker, a pipette, a $500 \mathrm{ml}$ Erlenmeyer, a heated magnetic stirrer, an analog multimeter and a thermometer. For the pilot conditions, a $316 \mathrm{~L}$ stainless steel tank with a capacity of 50 liters for ethoxide was formed, a stainless steel reactor with a capacity of 100 liters for obtaining esters associated with a mechanical stirrer controlled by a reducing motor with a speed variator and a control board. The temperature measurement was made by type $\mathrm{K}$ thermocouples (ChromelAlumel) processed with an Agilent HP model 34970A. For the analysis and characterization of the specific mass an Ostwald viscometer, water content was used using a coulumetric Karl Fischer titrator (ASTM D6304), oxidative stability index (IEO) by the Rancimat method (EN14112), acidity index, by potentiometric titration ASTM 664.

The preparation was divided into pre-treatment stages and the biodiesel production stage. The pretreatment was used only for the residual frying oil, the vegetable oil residues were filtered using 200,150 and 50 micron sieves, after the extraction of the mineral salts, proteins, phosphates and other compounds by the hydration method; then water $(0.15 \mathrm{v} / \mathrm{v})$ was added to prevent the increase in acidity and finally the drying process was carried out to remove the water present in the solute at a temperature of $110^{\circ} \mathrm{C}$ for 40 minutes, to avoid degrading The raw material. For the biodiesel production stage: the tests were initially carried out at the laboratory scale and then at the pilot plant scale. In laboratory scale: the reagents were processed in a $500 \mathrm{~mL}$ glass. The ethoxide was prepared by dissolving potassium hydroxide in ethanol according to stoichiometry. The residual pretreated frying oil $(200 \mathrm{~mL})$ was placed in a $500 \mathrm{~mL}$ glass on a heated magnetic stirrer. The system was stirred and heated to 60 ${ }^{\circ} \mathrm{C}$. The ethoxide was added slowly until the end and two hours were expected for the reaction. The conversion of oil into esters was verified by chromatography. After separation by decantation, the washing process was carried out. The process consisted of adding $40 \mathrm{ml}$ of distilled water to the Becquer with constant stirring for 10 minutes and then decanting in a separatory funnel, four washes were necessary. Finally, the evaporation process was carried out to separate water, alcohol, glycerin and traces of potassium hydroxide at a temperature of $100^{\circ} \mathrm{C}$ for 80 minutes.

\section{RESULTS AND DISCUSSION}

The presentation of the results with the respective discussions is divided into items: Physical-chemical characterization of residual frying and sunflower oil, Mass balance in biodiesel production at laboratory scale and biodiesel characterization. As a general rule, the purer the raw material, the easier the conversion into biodiesel. On the other hand, the cheaper the raw material, the more difficult and expensive it will be to convert it into biodiesel. Table 1 presents the physicochemical properties of the residual frying oil, such as specific mass, kinematic viscosity, water content and acidity index.

Table 1: Physicochemical properties of residual oil frying.

\begin{tabular}{ccc}
\hline Property & Frying residual oil & Sunflower oil \\
\hline $\begin{array}{c}\text { Specific mass to } 20^{\circ} \mathrm{C}, \\
\mathrm{kg} / \mathrm{m} 3\end{array}$ & $980,1 \pm 1,0 \%$ & $920,3 \pm 1,0 \%$ \\
$\begin{array}{c}\text { Kinematic viscosity to } 40 \\
{ }^{\circ} \mathrm{C}, \mathrm{mm} 2 / \mathrm{s} \\
\text { Water content }(\mathrm{Karl} \\
\text { Fischer), } \mathrm{mg} / \mathrm{kg}\end{array}$ & $40,8 \pm 1,0 \%$ & $30,4 \pm 1,0 \%$ \\
Acidity index, mg KOH/g & $0,98 \pm 1,5 \%$ & $305 \pm 0,1 \%$ \\
\hline
\end{tabular}


Table 1 shows that each of the initial parameters of the residual frying oil and sunflower oil is within the limits established by the Peruvian Technical Standard. Comparing both oils, it is observed that sunflower oil has lower specific mass, higher viscosity, and low acidity. The higher the density and viscosity, the lower the conversion of triglycerides, due to resistance to mass transport. On the other hand, the greater the amount of water, the greater the possibility of obtaining soaps. Finally, the higher acidity, the greater the likelihood of soap formation, producing water and lower the conversion of triglycerides

Table 2: Mass balance in biodiesel production.

\begin{tabular}{ccccc}
\hline \multirow{2}{*}{ Input } & \multicolumn{2}{c}{ Frying waste oil } & \multicolumn{2}{c}{ Óleo de girassol } \\
\cline { 2 - 5 } & Input (g) & Output $(\mathrm{g})$ & Input $(\mathrm{g})$ & Output $(\mathrm{g})$ \\
\hline Oil & 196,0 & -- & 184.1 & -- \\
Ethanol & 79 & -- & 79 & -- \\
KOH & 3 & -- & 3 & 48.11 \\
Glycerol & -- & 87,6 & -- & 1 \\
Ester & -- & 138,8 & -- & 165 \\
Excess Ethanol & -- & 48,7 & -- & 50 \\
Lost by manipu- & -- & 3,0 & -- & 3 \\
lation & & 85.2 & \multicolumn{2}{c}{266.1} \\
Yield & 68.5 & & &
\end{tabular}

In Table 2 it is observed that the yield of frying residual acceptance was $68.5 \%$ and using sunflower acceptance yielded the highest yield, $85.2 \%$. It is also observed that the characteristics of the production of biodiesel used from residual acceptance of frying, present conditions SST and its condition of increase of hygroscopicity of this residual acceptance.

The biodiesel samples obtained were analyzed by physicochemical tests, such as specific mass, kinematic viscosity, water content, acidity and oxidative stability index, as can be observed in Table 3 .

Table 3: Characterization of biodiesel obtained from residual vegetable acceptance and sunflower.

\begin{tabular}{ccccc}
\hline PARAMETERS & $\begin{array}{c}\text { NTP 321.125- } \\
2008\end{array}$ & METHOD & $\begin{array}{c}\text { Frying } \\
\text { residual oil } \\
\text { biodiesel }\end{array}$ & $\begin{array}{c}\text { Girassol oil } \\
\text { biodiesel }\end{array}$ \\
\hline $\begin{array}{c}\text { Specific masa, } \\
20^{\circ} \mathrm{C}, \mathrm{kg} / \mathrm{m} 3 \\
\text { Kinematic } \\
\text { viscosity, } 40^{\circ} \mathrm{C}, \\
\mathrm{mm} 2 / \mathrm{s}\end{array}$ & $850-900$ & $\begin{array}{c}\text { ASTM D } \\
4052\end{array}$ & $874,7 \pm 1,0 \% 880 \pm 1,0 \%$ \\
$\begin{array}{c}\text { Water content, } \\
\mathrm{mg} / \mathrm{Kg}\end{array}$ & Máx. 500 & $\begin{array}{c}\text { ASTM D } \\
6304\end{array}$ & $739,7 \pm 0,1 \%$ & $\begin{array}{c}514,3 \pm \\
0,1 \%\end{array}$ \\
$\begin{array}{c}\text { Acidity level, mg } \\
\text { KOH/g }\end{array}$ & Máx. 0,5 & ASTM D 664 & $0,3 \pm 1,5 \%$ & $0,3 \pm 1,5 \%$ \\
$\begin{array}{c}\text { Oxidative Stability } \\
\text { Index (IEO) }\end{array}$ & Mín. 3 horas & EN 14112 & $1,5 \pm 0,5 \%$ & $2,3 \pm 0,5 \%$ \\
\hline
\end{tabular}

It is observed that the parameters analyzed for the biodiesel of both raw materials are within the acceptable range, with the exception of the water content and the stability index. The residual frying oil has a high water content and a lower oxidative stability index, which means less storage stability time and possible deterioration due to the growth of bacteria, which can corrode the containers that contain them.

\section{DISCUSSION AND CONCLUSION}

The production of biodiesel and the ethanol-based transesterification methodology, demonstrates a yield above $68 \%$, referring to the balance obtained by the lipids R. Microbial toruloids studied from INRS (Lalit R Kumar, 2018), referring to the viscosity of According to the methyl esters of the different oils (Benjamin M. Wood, 2014), some studies determine the conditions of purification by esterification of this type of residual oil as a function of costs, establishing the use of bioethanol which improves the processes of esterification and transesterification (Nghiep Nam Tran, 2018), another fundamental aspect is the molecular composition, established by the viscosity and its volatility, as well as the chemical characteristics of the fuel, which govern the combustion reactions in terms of the initial conditions and the duration of combustion and its energy release rates (Ali MAAttia, 2015), while the ref Efficiencies for obtaining biodiesel suggest conditions of external influence and $\%$ relative humidity and its availability of storage related to hygroscopicity (Jimenez H. G, 2017).

Obtaining biodiesel from residual frying oil in general was satisfactory, not to the extent that the process should be energized to avoid the peculiar hygroscopicity of biodiesel, that the presence of water and the low oxidative stability index (IEO), establish their storage quality, being improved with the addition of antioxidants.

Despite the low yield of biodiesel obtained from residual frying oil (68.5\% compared to $85.15 \%$ of vegetable oil), it has a great social and economic impact due to the use of this residual oil and the ethyl route.

\section{REFERENCES}

1. Abd El-Fatah Abomohra, A. H.-N. (2017). Potential of macroalgae for biodiesel production: Screening and evaluation studies. Journal of Bioscience and Bioengineering, 231-237.

2. Ali M.A. Attia, A. E. (2015). Influence of diesel fuel blended with biodiesel produced from waste cooking oil on diesel engine performance. Fuel, 316-328.

3. Benjamin M. Wood, K. K. (2014). Study of combustion performance of biodiesel for potential application in motorsport. Journal of Cleaner Production, 5067.

4. Chunfeng Song, Q. L. (2016). Evaluation of hydrolysisesterification biodiesel production from wet microalgae. Bioresource Technology, 747-754.

5. G. Baskar, A. G. (2017). Optimization and kinetics of biodiesel production from mahua oil using manganese doped zinc oxide nanocatalyst. Renewable Energy, 641-646.

6. Ivanna Rivera, G. V. (2009). Producción de biodiesel a partir de residuos grasos animales por vía enzimática. GRASAS Y ACEITES, 468-474.

7. J. Dantas, E. L. (2018). Biodiesel Production Evaluating 
the Use and Reuse of Magnetic Nanocatalysts $\mathrm{Ni0.5Zn0.5Fe2O4.} \mathrm{Arabian} \mathrm{Journal} \mathrm{of} \mathrm{Chemistry,}$ 2375.

8. Ji Zhang, W. J. (2013). Effects of ambient oxygen concentration on biodiesel and diesel spray combustion under simulated engine conditions. Energy 57 (2013) $722 \mathrm{e} 732,722 \mathrm{e} 732$.

9. Jiaxin Chen, J. L. (2018). The potential of microalgae in biodiesel production. Renewable and Sustainable Energy Reviews, 336-346.

10. Jimenez H. G, C. E. (2017). Determination of Techniques of Impedance Electrochemical in Degradation Hygroscopic for Biodiesel and Blends. International Journal on Power Engineering and Energy, $2314-7318$.

11. K.A. Abed, A. E. (2018). Effect of waste cooking-oil biodiesel on performance and exhaust emissions of a diesel engine. Egyptian Journal of Petroleum, 11100621.

12. Lalit R Kumar, S. K. (2018). Energy balance for biodiesel production processes using microbial oil and scum . Bioresource Technology, 20635.

13. Mariana Lara Menegazzo, B. F. (2015). Production of biodiesel via methyl andethyl routes fromNile tilapia and hybrid Sorubim crude oils. Journal of Environmental Chemical Engineering, 150-154.

14. Nghiep Nam Tran, M. T. (2018). Scale-up and economic analysis of biodiesel production from recycled grease trap waste. Applied Energy, 142-150.

15. Rocio Maceiras, M. R. (2011). Macroalgae: Raw material for biodiesel production, Angeles Cancela, . Applied Energy, 3318-3323.

16. Sahar, S. S.-u.-R. (2018). Biodiesel production from waste cooking oil: An efficient technique to convert waste into biodiesel. Sustainable Cities and Society, 220-226.

17. Shubhangi S. Nigade, S. D. (2015). Development of Transesterification System with Acid and Base Homogeneous Catalysts For Mangifera Indica Seed Oil to Mangifera Indica Methyl Ester (MOME Biodiesel). International Journal of Energy and Power Engineering, 48-53.

18. Thalles A. Andrade, M. M. (2018). International Journal of Energy and Power Engineering Immobilized Enzymes: Optimization and Economic Analysis. Chemical Engineering Research and Design, 3396.

19. Thangavel Mathimani, N. M. (2018). A comprehensive review on harvesting of microalgae for biodiesel Key challenges and future directions. Renewable and Sustainable Energy Reviews, 1103-1120.

20. Wang Yi, F. S. (2015). Scum sludge as a potential feedstock for biodiesel production from wastewater treatment plants. Waste Management, 956-053. 